\title{
Development of Mint (Mentha piperita L.) Grown on Biosolids. Evaluation of Productivity and Essential Oil Content
}

\author{
Joseane Scavroni ${ }^{1}$, Leonardo Cesar Ferreira ${ }^{1}$, Janice Valmorbida ${ }^{2}$ and Carmen Sílvia \\ Fernandes Boaro ${ }^{1 *}$ \\ ${ }^{I}$ Departamento de Botânica; Instituto de Biociências; Universidade Estadual Paulista Júlio de Mesquita Filho; \\ C.P.: 510; 18618-000; Botucatu - SP - Brasil. ${ }^{2}$ Departamento de Produção Vegetal; Faculdade de Ciências \\ Agronômicas; Universidade Estadual Paulista Júlio de Mesquita Filho; 18603-970; Botucatu - SP - Brasil
}

\begin{abstract}
Development of Mentha piperita L on biosolids amended soil with levels equivalent to 0, 28, 56 and 112 tha was $^{-1}$ evaluated. In order to measure the productivity and its relation with mint essential oil yield, different indices were determined: leaf area, total and several organ dry matter, leaf area ratio, specific leaf area, net assimilation rate and relative growth rate at 30,44, 58, 72 and 86 days after planting (DAP), and essential oil yield at 90, 110 and 120 DAP. Physiological indices revealed that biosolids prolonged the vegetative phase of the plants, which adapted themselves to the presence of biosolids with time. Plants showed inverse behaviors in relation to productivity, resulting from the primary metabolism, represented by the shoot dry matter yield, and oil yield, resulting from the secondary metabolism. Adaptation of the mint plants to the growth on biosolids could be due to a phytoremediation function of this species. The intrinsic mechanisms of these processes could be better understood in a further evaluation of residual effects in mint plant shoots.
\end{abstract}

Key words: Growth analysis; peppermint, essential oil, sewage-sludge, leaf area, dry matter

\section{INTRODUCTION}

Biosolids are solids residue produced by sewage treatment process. Social and environmental requirements to give an adequate destination to biosolids have stimulated the use of this material as soil fertilizer or conditioner. This alternative allows the utilization of minerals and organic matter present in sewage-sludge, which can be beneficial for the soil structure and fertility, and, consequently, for the growth of the plant species cultivated in such soils (Melo and Marques, 2000; Tsutya, 2000).

However, there are restrictions for the use of biosolids from sewage of metropolitan regions because of mineral imbalance, high levels of heavy metal (Bettiol and Camargo, 2000), ammonia volatilization and increase of soil salinity, when the residue is applied at elevated concentrations (Bugbee, 2002).

Zheljazkov and Nielsen (1996) reported a decrease from 9 to $16 \%$ of mint fresh matter grown in high concentrations of $\mathrm{Cd}, \mathrm{Pb}, \mathrm{Cu}, \mathrm{Mn}$ and $\mathrm{Zn}$.

\footnotetext{
* Author for correspondence: csfboaro@ibb.unesp.br
} 
However, Scora and Chang (1997) have grown Mentha piperita $\mathrm{L}$. in soil containing different $\mathrm{Cd}$ concentrations, from biosolids, and observed that phytomass was not affected. In both studies, the authors considered Mentha piperita L. as a phytoremediator of soil contaminated with heavy metals, since it was able of developing without accumulation of these metals in its tissues. Bugbee (2002) studied the development of several herbaceous species at high biosolids levels and observed that part of them died while other plants remained chlorotic for several weeks after planting, probably because of the high level of salinity and ammonia.

Some studies have demonstrated the positive effects of biosolids application for the cultivation of different species depending on the level used. Tsutya (2000) reported that the presence of biosolids was beneficial to soil structure and fertility, and that biosolids amended soils contributed for the development and productivity of the plants.

Mentha piperita L., known as mint or peppermint, is a Lamiaceae that produces essential oil resulting from its secondary metabolism; the oil is rich in menthol, which is a component with great importance in perfume and essence industries (Lorenzi and Matos, 2002). According to Scora and Chang (1997), mint is easily adaptable to different climate and soil conditions. However, some studies have established that a satisfactory development depends on suitable environmental conditions, including mineral nutrition (Piccaglia et al., 1993; Patra and Anwar, 2000; Leal, 2001).

Essential oil of M. piperita L. is extracted from the shoot, mainly from the plant leaves, and oil content can be related to matter accumulation in these parts (Clark and Menary, 1980; Czepak, 1998). According to Czepak (1998), the higher the yield of dry matter of plants, the higher the essential oil yield would be. However, Scora and Chang (1997) did not observe differences in oil yield among the plants grown with biosolidamended applications at 100 days following transplanting. Topalov and Zhelyazkov (1991) observed higher oil yield when $M$. piperita L. plants grown without biosolids were harvested between 97 and 100 days after planting.

Mata-González et al. (2002) have pointed out the lack of information about the physiological mechanisms involved in increase of phytomass yield in the plants fertilized with biosolids. In general, there are many studies that have attempted to evaluate the dry matter produced by the plant and leaf area, but without references to the mechanisms involved in the production. Thus, the growth analysis, which describes the plant morphophysiological conditions at different time intervals (Magalhães, 1986), can facilitate a follow-up of the dynamics of plant productivity when a species is grown in the presence of solid residues. Productivity is associated to several characteristics of the species, which interact in a complex manner with the environment (Bacarin and Mosquin, 1997). Growth analysis is based on the fact that about $90 \%$ of the dry matter accumulated by the plants during growth comes from its photosynthetic activity and the rest from mineral nutrient uptake, also essential for plant growth and development (Benincasa, 2003). Evaluation of dry matter can be done using several physiological indexes (Benincasa, 2003) such as: leaf area ratio (LAR) that expresses useful leaf area for photosynthesis, specific leaf area (SLA) that reflects the inverse of leaf thickness, net assimilation rate (NAR) that measures net photosynthesis, and relative growth rate (RGR) that represents size increase in relation to existing dry matter at the moment the period of observation starts.

The present study aimed at evaluating the productivity and essential oil content of $M$. piperita L. plants grown in different levels of biosolids.

\section{MATERIALS AND METHODS}

M. piperita L. plants from Departamento de Produção Vegetal of Faculdade de Ciências Agronômicas of UNESP, Botucatu Campus, SP, Brazil, were used. The experiments were conducted from February to June, 2003. Approximately $10 \mathrm{~cm}$ long stem fragments were placed and maintained in a $\mathrm{KNO}_{3}$ solution at a concentration of $0.6 \mathrm{~g} \mathrm{~L}^{-1}$ during 15 days for rooting. Seedlings (two per $5.5 \mathrm{~L}$ pot) were then transferred and maintained in a greenhouse at Departamento de Botânica of Instituto de Biociências, UNESP, Botucatu Campus, São Paulo, Brazil, under the following conditions: mean maximum and minimum temperatures of 32.5 and $13.6^{\circ} \mathrm{C}$, respectively, mean relative humidity of $66 \%$, and mean global solar radiation of $234.78 \mathrm{cal} \mathrm{cm}^{-2}$ day $^{-1}$. 
A dark red dystrophic Latosol treated with lime was used to prepare the cultivation substrate. The biosolids used in the experiment (Table 1) were obtained from the Barueri Sewage Treatment Station (STS), in the metropolitan region of São Paulo, SP, Brazil.

The NPK macronutrients in the Barueri STS biosolids were measured and it was observed that $\mathrm{K}$ was with the lowest concentration; $\mathrm{K}$ concentration was then used as a reference to define all the treatments, which were defined by different levels of biosolids at which plants should grow. The amount of $\mathrm{K}$ recommended for the conventional mint fertilization was found in the lowest biosolids level. Based on this, the treatments were $0 \mathrm{t} \mathrm{ha}^{-1}$, a control prepared based on chemical fertilization, according to specifications of Van Raij et al. (1996), and treatments containing the equivalent to $28 \mathrm{t} \mathrm{ha}^{-1}$ biosolids (14 g biosolids $\mathrm{kg}^{-1}$ dirt), $56 \mathrm{t} \mathrm{ha}^{-1}$ biosolids ( $28 \mathrm{~g}$ biosolids kg-1 dirt), and $112 \mathrm{t} \mathrm{ha}^{-1}$

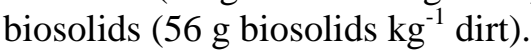

Evaluation of productivity was done at five harvests performed at 30, 44, 58, 72 and 96 days after planting (DAP). For this, the plants were separated in stems plus petioles, roots and leaf blades; leaf area was determined, in $\mathrm{dm}^{2}$, using a model LI 3100 area meter. Leaf blades and other parts were dried in a forced air circulation oven at $60^{\circ} \mathrm{C}$ for $72 \mathrm{~h}$. The dry matter of the different parts was determined in an Ohaus Analytical Standard analytical scale with $0.1 \mathrm{mg}$ readability. Before estimating the physiological index of growth analysis - leaf area ratio (LAR), specific leaf area (SLA), net assimilation rate (NAR) and relative growth rate (RGR) - the variables corresponding to leaf area, leaf blade dry matter and total dry matter of plants were adjusted in relation to time, i.e., age of plants, through a computational program ANACRES, according to specifications of Portes and Castro Júnior (1991). In the present study, such adjustments were done through a square exponential equation.

Total fresh matter in plant shoots was determined at three harvesting seasons (90, 110 and 120 DAP) after drying in a forced aeration oven at $35^{\circ} \mathrm{C}$ until constant dry matter value was achieved. The dry matter was then submitted to hydrodistillation in a Clevenger-type device for two hours in order to extract the oil, allowing oil yield to be calculated as $\mathrm{mL} 100 \mathrm{~g}^{-1}$ dry matter (DM).

Results were submitted to an F test through regression analysis of variance (SAS, 1996), at 5\% probability, using a completely randomized $4 \times 5$ factorial arrangement with four replicates for dry matter yield and leaf area, whereas a completely randomized $4 \times 3$ factorial arrangement with three replicates was used for essential oil content.

Models of polynomial regression were done when significant interaction between biosolids levels and days after planting (biosolids levels x DAP) were observed. In the harvest periods in which such interaction was not observed, only points referring to each biosolids level were plotted in the graphics, without a tendency line between them. When the model represented mean values of all the harvest periods, at each biosolids level, the interaction biosolids levels $\mathrm{x}$ DAP was not observed in any harvest. This was the case for shoot dry matter and essential oil content.

\section{RESULTS AND DISCUSSION}

When leaf blade dry matter was analyzed, a significant interaction between biosolids level $\mathrm{x}$ DAP at 30 and 44 DAP was observed (Fig. 1).

Thus, a reduction in leaf blade dry matter was observed at the beginning of the cycle as the levels of biosolids used in mint cultivation increased. With time, mint plants seemed to have adjusted to the cultivation conditions in the presence of biosolids, because they no longer showed differences in dry matter values when grown in the presence of different levels of solids residues. These results were in agreement with those of Zheljazkov and Nielsen (1996) and Scora and Chang (1997), because the mint plants were capable of developing without accumulation of these metals in their tissues.

When mint plants were evaluated as for dry matter of stem plus petiole (Fig. 2), a significant interaction between biosolids level x DAP was observed.

As expected, the values of these variables were higher as plant developed; however, in general, a decrease with higher biosolids levels in all evaluations was seen. 


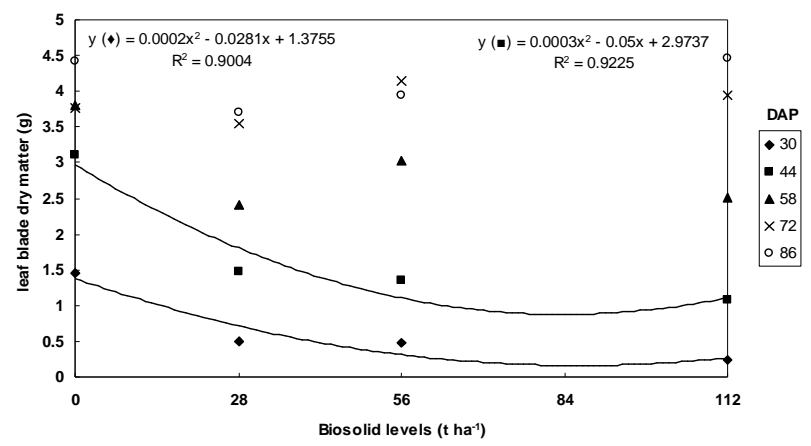

Figure 1 - Leaf blade dry matter (g) of Mentha piperita L. plants grown in the presence of different levels of biosolids, at 30, 44, 58, 72 and 86 days after planting (DAP). Means of four replicates. At 58, 72 and 86 DAP, leaf blade dry matter of plants submitted to different levels of biosolids did not differ at $\mathrm{p}>0.05$ - with no adjustment.

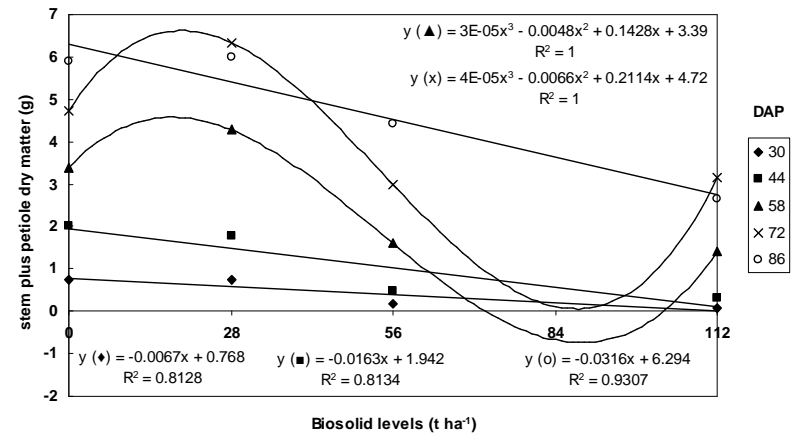

Figure 2 - Stem plus petiole dry matter (g) of Mentha piperita L. plants grown in the presence of different levels of biosolids, at five harvest periods, at 30, 44, 58, 72 and 86 days after planting (DAP). Means of four replicates.

These results, which referred to plant cultivation with increasing potassium levels due to an increase in the amount of biosolids, were not in agreement with those of Valmorbida et al. (2007b). They observed a raise tendency for stem plus petiole dry matter in M. piperita L. plants grown in nutrient solution with increased $\mathrm{K}$ levels. In the present study, possibly because of a potassium increase with biosolids application, other harmful elements or those that competed with $\mathrm{K}$ in plant development might have been higher. In the work of Valmorbida et al. (2007b), only potassium level was increased in the nutrient solution. It should be noted that the adjustment curves of biosolid levels at different periods varied and showed similar behaviors at 33,44 and 86 DAP, and at 58 and 72 DAP. Thus, plants showed more variation in the most intermediate phases of their cycle, with a more uniform behavior at the beginning and end of the evaluation.

No significant interaction between biosolids level $x$ DAP (Fig. 3) was observed in the evaluation of shoot dry matter. In this case, the curve represented the means of five harvest periods at each biosolids level.

These results agreed with Scora and Chang (1997), who did not observe alterations of this variable in $M$. piperita $\mathrm{L}$. plants grown on the soils with $\mathrm{Cd}$ concentrations equals to $0.12 ; 0.6 ; 1.9 ; 4.2$ and 6.1 $\mathrm{mg} \mathrm{kg}^{-1}$, due to the use of biosolids. In the present study, although the plants grown in the absence of biosolids showed, on average, slightly higher values for shoot dry matter in all evaluation periods, differences were not observed at 5\% significance level. Again, the results suggested a plant adaptation to biosolids levels with time and 
its possible soil phytoremediator function. Even the variations observed in stem plus petiole dry matter were minimized when the whole shoot was evaluated. In the present work, the Cd level, equal to $10.90 \mathrm{mg} \mathrm{kg}^{-1}$ (Table 1), was higher than the level evaluated by Scora and Chang (1997).

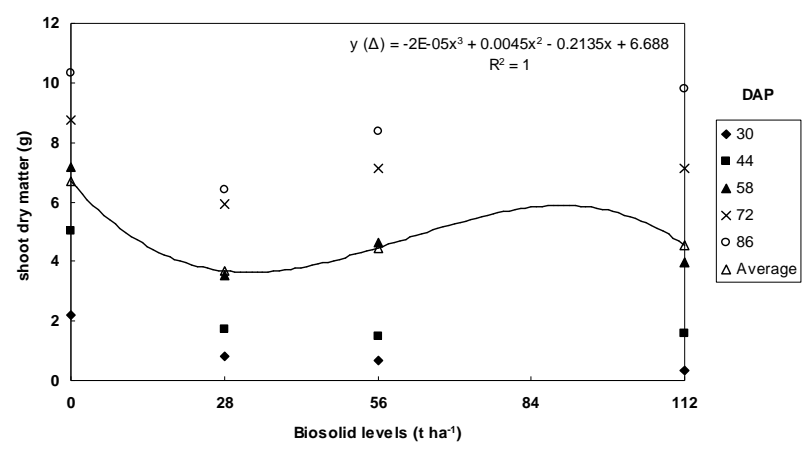

Figure 3 - Shoot dry matter (g) of Mentha piperita L. plants grown in the presence of different levels of biosolids. Means of four replicates. No significant interaction between biosolids level x DAP was observed at 30, 44, 58, 72 and 86 DAP. The curve indicates mean adjustment of five harvest periods at each biosolids level.

Table 1 - Composition of biosolids obtained from the Barueri Sewage Treatment Station (STS), in the metropolitan region of São Paulo, SP, Brazil, used to grow Mentha piperita L. plants.

\begin{tabular}{|c|c|c|c|c|c|c|c|c|}
\hline pH & $\mathbf{C u}$ & $\mathrm{Fe}$ & $\mathbf{Z n}$ & Mn & B & $\mathrm{Na}$ & Cd & $\mathbf{P b}$ \\
\hline 7.30 & 570.00 & 39320.00 & 2381.00 & 194.00 & 9.00 & 583.00 & 10.90 & 165.00 \\
\hline $\begin{array}{r}\text { org } \\
\text { total }\end{array}$ & $\begin{array}{l}\text { c matter } \\
\text { composted }\end{array}$ & $\mathbf{S}$ & $\mathbf{P}$ & $\begin{array}{l}\mathbf{K} \\
\%\end{array}$ & $\mathbf{N}$ & $\mathrm{Ca}$ & Mg & $\begin{array}{c}\mathrm{C} \\
\text { organic }\end{array}$ \\
\hline 54.64 & 52.52 & 0.66 & 3.27 & 0.27 & 3.27 & 2.52 & 0.49 & 29.20 \\
\hline
\end{tabular}

A significant interaction between biosolids level $\mathrm{x}$ DAP in root dry matter of mint plants (Fig. 4) was observed. In all evaluation periods, a higher value for root dry matter was observed in the plants grown without biosolid.

The increase in the residue levels was accompanied by a decrease in root dry matter, which suggested the phytoremediator action of mint plants (Zheljazkov and Nielsen, 1996; Scora and Chang, 1997). Maisonnave et al. (2002) observed that the roots of grass plants grown on biosolids assimilated high levels of heavy metals obstructing their translocation to other plant parts. The same behavior might have occurred in mint plants grown on biosolids amended soil, allowing the assimilation of elements that existed in higher concentrations in the biosolids, thus explaining the lower development of mint roots.

As a consequence of the influence of biosolids on plant roots, total dry matter also showed a significant interaction between biosolids level $\mathrm{x}$
DAP in mint (Fig. 5). In all evaluation periods, higher total dry matter was observed in the plants grown without biosolids, and a decrease, in general, was observed as biosolids level increased. In the total dry matter, $51 \%$ on the average corresponded to shoot dry matter and $49 \%$ to root dry matter in the plants grown without biosolids. When plants were submitted at $28 \mathrm{t} \mathrm{ha}^{-1}$ of biosolids, $58 \%$ corresponded to shoot dry matter and $42 \%$ to root dry matter. In those plants grown with $56 \mathrm{t} \mathrm{ha}^{-1}$ of biosolids, $63 \%$ of total dry matter corresponded to shoot and $37 \%$ to root dry matter, and in those grown with $112 \mathrm{t} \mathrm{ha}^{-1}$ of biosolids, $78 \%$ referred to shoots and $22 \%$ to the roots. The use of sewage-sludge for mint cultivation evidently influenced the partition of assimilates between shoot and root. Thus, it is relevant to point out the high percentage of shoot dry matter in plants grown in the presence of the highest biosolids level. 


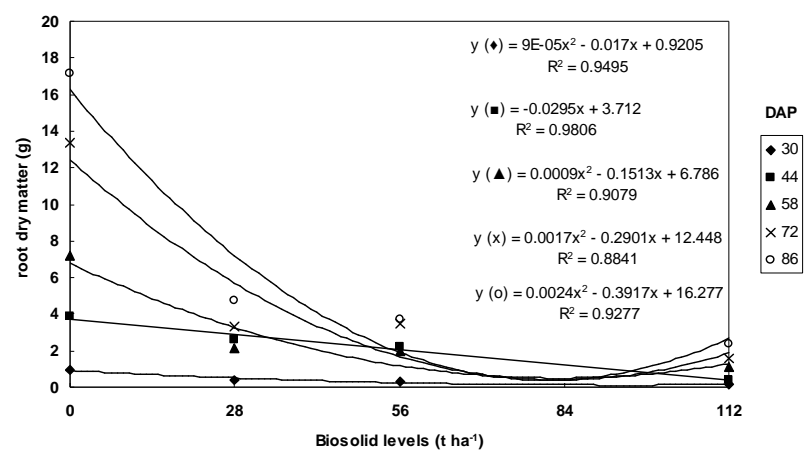

Figure 4 - Root dry matter ( $\mathrm{g}$ ) of Mentha piperita L. plants grown in the presence of different levels of biosolids, at five harvest periods, at 30, 44, 58, 72 and 86 days after planting (DAP). Means of four replicates.

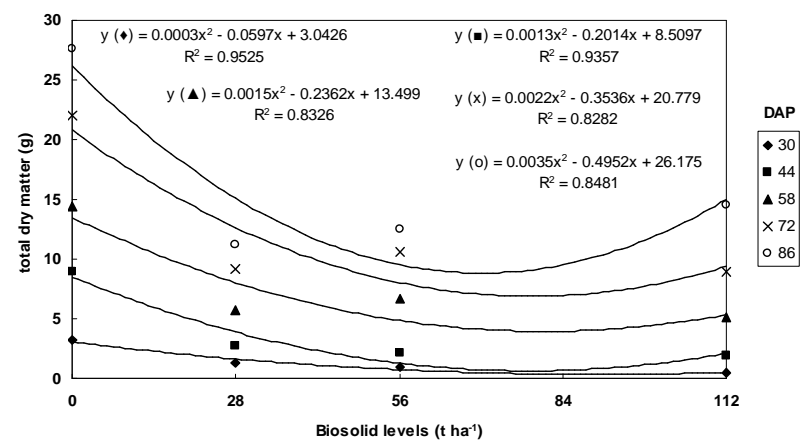

Figure 5 - Total dry matter (g) of Mentha piperita L. plants grown in the presence of different levels of biosolids, at five harvest periods, at 30, 44, 58, 72 and 86 days after planting (DAP). Means of four replicates.

Since shoot dry matter can be involved with essential oil yield, the higher yield of this matter the higher essential oil yield is expected (Munsi, 1992; Czepak, 1998). On the other hand, therpenoid biosynthesis occurs in oil epidermal glands, which are carbon consumers (Croteau and Johnson, 1984). Consequently, epidermal glands depend on adjacent photosynthesizing cells for a continuous supplement of carbon precursors (Srivastava et al., 1994). Thus, based on these observations, it can be inferred that higher carbon transfer to oil epidermal glands may result in smaller accumulation of dry matter.

Valmorbida et al. (2007b) grew M. piperita L. in nutrient solution with different $\mathrm{K}$ levels and observed that from the total dry matter produced, $78 \%$ were in shoots. The elements which plants need are not always easily available in soils or substrates on the cultivation condition of the present research, thus a greater development of the root system for their uptake is required. On the other hand, in nutrient solutions as described by Valmorbida et al. (2007b), all ions become soluble, which facilitates their uptake by roots. In this case, roots do not need to occupy a very great area for their development (GEPEQ, 2006).

A significant interaction between biosolids levels $x$ DAP was observed in mint leaf area at $30,44,58$ and 72 DAP (Fig. 6). Thus, at the beginning of the cycle, at 30 and 44 DAP, a leaf area and blade reduction was observed. However, in a later cycle phase, at 58 and 72 DAP, there was a increase in leaf area in plants treated with $56 \mathrm{tha}^{-1}$ of biosolid. Watson (1952) reported that plant leaf area was very dependent on mineral nutrition. Nutrient availability is one of the main factors that determine crop productivity. Thus, 
deficiency of micronutrients has been related to several factors such as increase in soil $\mathrm{pH}$ (Consolini and Coutinho, 2004). Pigozzo et al. (2006) reported that application of sewage sludge caused a slight $\mathrm{pH}$ rise in the soil; later $\mathrm{pH}$ lowered and remained similar to the initial level. In the present work, the smaller leaf area showed by plants grown in the presence of biosolids at the beginning of the cycle can be attributed to a possible increase of soil $\mathrm{pH}$, due to ammonia release from the decomposition of organic compounds present in the residue (Lund and Doss, 1980; Berton et al., 1989; Borges and Coutinho, 2004). This might had led to a lower availability of essential elements.

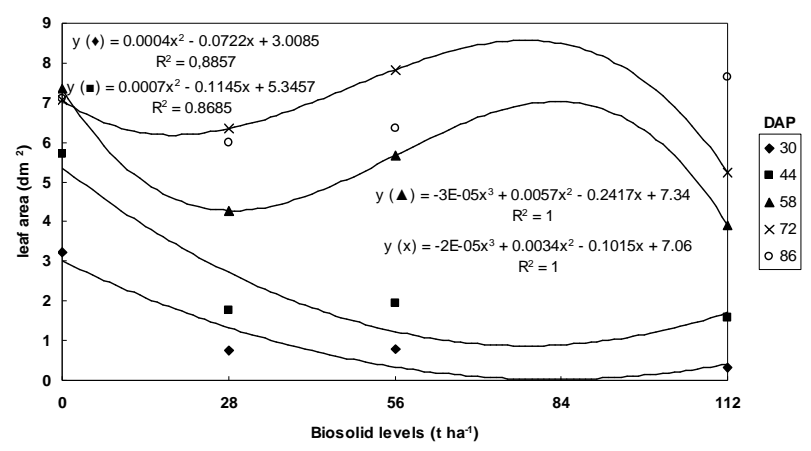

Figure 6 - Leaf area $\left(\mathrm{dm}^{2}\right)$ of Mentha piperita L. plants grown in the presence of different levels of biosolids, at five harvest periods, at 30, 44, 58, 72 and 86 days after planting (DAP). Means of four replicates. At 86 DAP, leaf area of plants submitted to different levels of biosolids did not differ at $\mathrm{p}>0.05$ - without adjustment.

Mata-González et al. (2002) grew grass plants on biosolids with levels varying between 0 and $90 \mathrm{mg}$ $\mathrm{ha}^{-1}$ and observed that increase in biosolid levels resulted in a increment in leaf area. However, the decrease in leaf area observed in the present work was not in agreement with those results obtained by these authors. It was possible that the levels of biosolids used in the present work, which varied between 0 and $112 \mathrm{t} \mathrm{ha}^{-1}$, i.e., much higher than those studied by Mata-González et al. (2002), could explain the difference verified.

While leaf area of plants grown without biosolids increased until 58 DAP, in those grown on biosolids an increase in leaf area occurred until 72 or 86 DAP, suggesting prolongation of the vegetative phase. This behavior was also observed by Korboulewsky et al. (2002), who reported flowering delay in Diplotaxis erucoides L. grown on biosolids, and by Brallier et al. (1996), who reported high residue levels inducing a delay in plant development. Such results can be explained by the higher level of $\mathrm{N}$ available to plants grown on biosolids (Salisbury and Ross, 1992). This was evident in the present work and also in the study of Bugbee (2002), possibly by $\mathrm{NH}_{3}$ volatilization from the residue used for the cultivation of mint and ornamental plants, respectively. Again, the biosolids effect was more noticeable in the results of the leaf area at the beginning of the development, and this difference disappeared with time, suggesting plant adaptation to growth on biosolids residue.

Plants grown in the presence of biosolids showed similar LAR behavior (Fig. 7a). Values differed from those showed by the plants grown in the absence of biosolids. These plants had higher LAR at 30 days after planting (DAP) showing a tendency for a uniform decrease in LAR during the cycle. Boaro et al. (1996), studying the development of Phaseolus vulgaris L. grown in nutrient solution with variation of magnesium levels have also observed a similar LAR behavior. Both studies revealed higher LAR at the beginning of development cycle, period in which an investment in leaf development occurred for luminous energy interception (Wallace and Munger, 1965; Brandes et al., 1973).

LAR in the plants grown in the presence of different levels of biosolids increased, generally, until 44 DAP, and then exhibited a decrease. At the end of the cycle, these plants showed higher LAR values than those observed in the plants grown without biosolid. Again, such behavior suggested prolongation of the vegetative phase of 
plants grown in the presence of biosolid, which might have occurred due to higher $\mathrm{N}$ levels provided by the residue. It should still be considered that nutrient requirement might not be initially satisfied; thus, it was not in excess at this phase, because its availability from biosolids depended on a period of adequate conditions of temperature and irrigation (Bettiol and Camargo, 2000). Thus, it could be suggested that mint plants showed adaptation to different levels of biosolids during the development cycle.

According to Benincasa (2003), LAR expresses the leaf area useful for photosynthesis and the relationship between leaf area responsible for light interception and $\mathrm{CO}_{2}$, and total dry matter resulting from photosynthesis. Thus, with the plant growth, there is more interference of higher leaves on lower ones, with a tendency to decrease the useful leaf area from certain phases. This behavior was observed in the plants grown in the absence of biosolids and, only later, in those grown in its presence. This LAR behavior was also observed by Ferreira (1996), who evaluated Zea mays L. plants grown at different potassium levels. Valmorbida et al. (2007a), studying the development of $M$. piperita L. grown in nutrient solution with variation of potassium levels, observed a LAR decrease after 21 days after transplanting, an initial phase of the cycle in which LAR showed higher value.

Specific leaf area (SLA) varied little along the cycle of plants submitted to different treatments (Fig. 7b). Boaro et al. (1996) evaluated Phaseolus vulgaris L. cv. Carioca plants in nutrient solution where magnesium levels varied and observed that SLA was kept practically constant. However, while this index showed a slight decrease in plants grown without biosolid, those grown in its presence, usually, showed a slight increase. This index, which was calculated through a relation between leaf area and leaf blade dry matter, followed the same tendency shown by leaf area values, i.e. higher in plants grown on biosolids residue.

Benincasa (2003) recorded higher SLA values at the beginning of the development revealing thick leaves, with lower dry matter and leaf area quantity. The results found for SLA of plants grown in the absence of biosolids were similar to their observations. With development of the plant, leaf area and leaf dry matter increase, with a tendency to decrease the value of SLA. Thus, prolongation of vegetative phase of plants grown in the presence of biosolids could also be suggested here.

Leal (2001) evaluated M. piperita L. in nutrient solution with different nitrogen levels and observed an SLA increase along the cycle, except in plants submitted to the highest nitrogen level, equal to $315 \mathrm{mg} \mathrm{L}^{-1}$ at the beginning of the cultivation and then diluted to $80 \%\left(158 \mathrm{mg} \mathrm{L}^{-1}\right)$. Increasing of SLA would be expected because nitrogen stimulates vegetative growth. Thus, the highest nitrogen level used $\left(315 \mathrm{mg} \mathrm{L}^{-1}\right.$ and 158 $\mathrm{mg} \mathrm{L}^{-1}$ ) might have been excessive for the plants.

Valmorbida et al. (2007a) observed SLA increase in $M$. piperita L. plants grown with varied potassium levels at three different treatments: 1) starting at $29.25 \mathrm{mg} \mathrm{L}^{-1}$ and then increased to $\left.58.50 \mathrm{mg} \mathrm{L}^{-1}, 2\right)$ starting at $58.50 \mathrm{mg} \mathrm{L}^{-1}$ and increased to $117.00 \mathrm{mg} \cdot \mathrm{L}^{-1}$ and 3) starting at $117.00 \mathrm{mg} \mathrm{L}^{-1}$ and then, $234.00 \mathrm{mg} \mathrm{L}^{-1}$. The results found in the present research in plants grown with biosolids agreed with the mentioned study. It should be emphasized that due to increase in biosolids level, a higher potassium level was possibly available for the plants.

NAR of plants submitted to treatments with 28,56 and $112 \mathrm{t} \mathrm{ha}^{-1}$ of biosolids showed a greater decrease with age (Fig. 7c). A different behavior was shown by plants grown without biosolids in which NAR increased slightly, generally, until 58 days after planting, followed by a decrease. According to Milthorpe and Moorby (1974), NAR frequently decreases with plant age due to inferior leaf screening. Thus, its decrease suggests growth. This was supported by results of Valmorbida et al. (2007a), who attributed NAR decrease in $M$. piperita L. grown in the presence of different potassium levels to the increase in leaf area, which was responsible for of the lower leaf.

Although LAR and SLA suggest prolongation of the vegetative phase of plants grown with biosolid, NAR, which reflects plant photosynthetic efficiency, decreases faster in these plants with age, an indicative of growth. Therefore, NAR demonstrates, more evidently, the plant adaptation to an adverse condition to which plants were submitted.

Mata-González et al. (2002) grew grass plants in the presence of biosolids and observed that the leaf area increase not always corresponded to a raise in the photosynthetic rate. In the present work, similarly, a direct relation between leaf area and photosynthetic rate was not seen when plants were grown in the presence of sewage-sludge. A direct 
relationship was observed in plants grown in the absence of the solids residues, where leaf area increase led to NAR increase. Again, plant adaptation to sludge was demonstrated. Although plants had decreased leaf area when grown in the presence of biosolids, they showed an adequate photosynthetic efficiency. It was worth observing again the lack of information about the physiological mechanisms involved in the phytomass yield in plants fertilized with biosolids (Mata-González et al., 2002).

In a study on development of Phaseolus vulgaris in nutrient solution, with variation of magnesium levels, Boaro et al. (1996) reported that NAR decreased before LAR decreases could be detected. These results were similar to those observed in different treatments in the present work.

In the harvests at 44, 58, 72 and 86 DAP NAR of the plants submitted to the different treatments, largely, showed values close to those seen at the beginning, a behavior also observed in other indices evaluated, except LAR. This also suggested plant adaptation to sewage-sludge.

Relative growth rate (TCR), usually, showed a similar behavior in plants submitted to different treatments, i.e. decreasing with time (Figure 7d). However, plants grown without biosolids or with the lowest biosolids level showed very similar results. This behavior could be considered another indicative of plant adaptation to adverse condition, which was more evident in plants grown with the lowest sludge level. The arguments used for NAR, LAR and SLA were also valid for RGR in the sense that this index was indicative of growth as well; the greater the decrease of its curve (Figure 7d) the better the expression of this index, a behavior observed in plants grown on the two highest biosolids levels, equivalent to 56 and $112 \mathrm{t}$ $\mathrm{ha}^{-1}$. Again, the highest nitrogen level provided to plants could have been responsible for this RGR behavior.

RGR, which represents dry matter increase of a plant, or of any one of its organs, in relation to the dry matter present at the moment in which the period of observation begins, not always detects differences among treatments (Benincasa, 2003). Valmorbida et al. (2007a) grew mint plants with potassium level variation and observed the same
RGR behavior among plants. In this case, detection of different effects of potassium levels through this variable was not possible either. In the present study, although results at the end of the cycle were similar in all plants, no difference in RGR was shown by the plants grown in the presence of the highest levels of biosolids.

RGR of plants grown on the highest levels of biosolids, at 56 and $112 \mathrm{t} \mathrm{ha}^{-1}$ were more elevated at the beginning of the cycle. Nutrient levels provided to the plants, considering the possible problems with their availability, were higher at these biosolids levels. This result was in agreement with those of Ferreira (1996), who observed higher RGR values in maize plants grown with higher potassium levels.

Although plants grown in the presence of biosolids had longer vegetative phase, as indicated by LAR and SLA, they were adapted to the presence of solid residues along the cycle, as revealed by NAR and RGR.

No significant interaction between biosolids levels $\mathrm{x}$ DAP in relation to mint essential oil yield was observed (Fig. 8). However, considering the means of harvest period at each biosolids level, the content was slightly higher in plants grown with biosolid, especially that at $28 \mathrm{t} \mathrm{ha}^{-1}$. Similar results were observed by Scora and Chang (1997) in $M$. piperita L., who did not observe oil yield differences among plants grown with biosolids applications at 100 days after transplanting. Although in the present work, a biosolids effect in essential oil yield was not observed, Scavroni et al. (2005) reported that biosolids promoted alterations on $M$. piperita L. essential oil composition under the same conditions used here.

For the essential oil content, which results from secondary metabolism, two considerations can be done. Biotic and abiotic factors can modify mint plant oil yield (Veronese et al., 2001). It is possible that the better performance of plants grown in the presence of sewage-sludge, indicated by NAR and RGR, results in a tendency to a better essential oil content. Plant adaptation might have led to an equilibrium of the primary and, consequently, secondary metabolism, since the two biosynthetic pathways were interrelated (Taiz and Zeiger, 2004). 

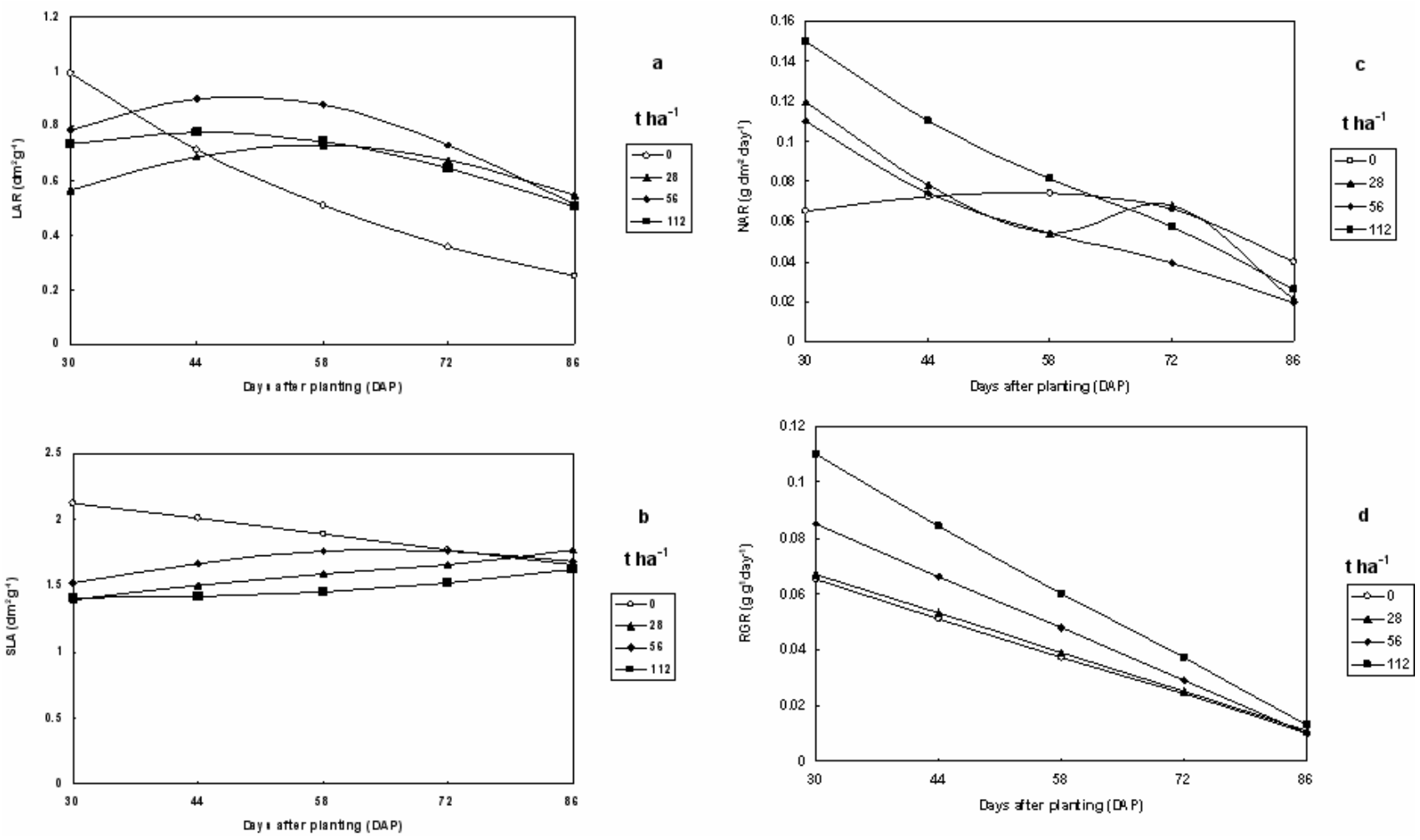

Figure 7 - a) Leaf area ratio (LAR), $\mathrm{dm}^{2} \mathrm{~g}^{-1}$, b) Specific leaf area (SLA), $\mathrm{dm}^{2} \mathrm{~g}^{-1}$, c) Net assimilation rate, (NAR), $\mathrm{g} \mathrm{dm}^{-2} \mathrm{day}^{-1}$, d) Relative growth rate (RGR), $\mathrm{g} \mathrm{g}^{-1}$ day $^{-1}$ of Mentha piperita L. plants grown in the presence of different levels of biosolids $(0,28$, 56 and $112 \mathrm{t} \mathrm{ha}^{-1}$ ), at several harvests. Means of four replicates. Values adjusted through a square exponential equation.

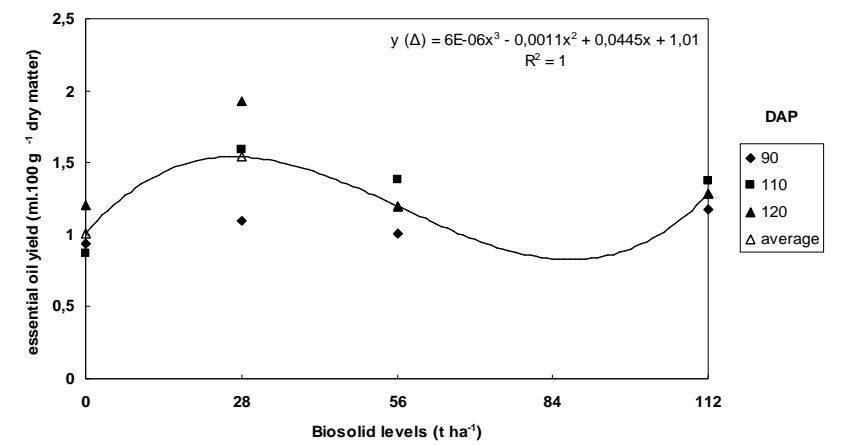

Figure 8 - Essential oil yield (mL $100 \mathrm{~g}^{-1}$ dry matter) of Mentha piperita L. plants grown in the presence of different levels of biosolids. Means of three replicates. At 90, 110 and 120 DAP, significant interaction between biosolids level x DAP was not observed. The curve indicates the mean adjustment of three harvest periods at each biosolids level. 
Topalov and Zhelyazkov (1991) observed higher oil yields, on average equal to $1 \mathrm{~mL} 100 \mathrm{~g}^{-1}$ dry matter, when $M$. piperita L. plants grown without biosolids were harvested between 97 and 100 DAP. Valmorbida et al. (2007a) studied mint plants grown on complete nutrient solution under the same climate conditions of the present study and observed mean oil yield of $1.27 \mathrm{~mL} 100 \mathrm{~g}^{-1}$ dry matter. Comparatively, the mean content of

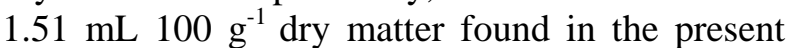
study, which was obtained with plants grown with $28 \mathrm{t} \mathrm{ha}^{-1}$ of biosolid, could be considered high and indicative of stress or adaptation to sludge. The results obtained in several works indicated discrepancy due to experimental conditions and harvest periods, variables in which plants were submitted, which interfered with mint essential oil content and composition (Reitsma et al., 1961; Marotti et al., 1997).

In the conditions of the present work, a high percentage of shoot dry matter was observed in plants grown with the highest biosolids level although increase in essential oil content was not observed. Figures 3 and 8 showed the inversely proportional behaviors for shoot dry matter and essential oil yield. Thus, although evaluation of plant productivity through physiological index of growth analysis indicated the possibility of cultivating this species in the presence of biosolids, plants with higher productivity would not have higher essential oil yield. Other factors may have influenced these results. This behavior was also observed by Fernandes et al. (2004), in which two species of Ocimum spp. were grown in a hydroponic system, and although fresh matter was increased, essential oil yield and composition were not altered.

Physiological indices evaluated under the conditions of this work allowed to conclude that biosolids promoted prolonged vegetative phase of mint plants. It could be suggested that plants adapted to presence of biosolids with the time, due to phytoremediator action. In addition, plants showed opposite behaviors for the productivity and essential oil yield. It could be said that growth analysis, which was the productivity measurement and was evaluated through physiological indices, not always reflected the yield (Benincasa, 2003). In the present work, mint plant productivity, based on shoot dry matter yield, obtained from primary metabolism, inversely correlated to essential oil yield, which resulted from the secondary metabolism. This could be explained by the metabolic pathways that competed by the same photosynthesized carbon precursors. However, it could be suggested that evaluation of residual effects of plant shoot should be done for confirmation of the phytoremediator function of mint plants and for a better understanding of the mechanisms involved in the process.

\section{ACKNOWLEDGEMENTS}

The authors wish to thank Conselho Nacional de Desenvolvimento Científico e Tecnológico/CNPq (Brazil) for financial support, Dr. Roberto Lyra Villas Boas, Dr. Wanderley da Silva Paganini, Dr. Luiz Antônio de Mendonça Costa and Dr. Mônica Sarolli Silva de Mendonça Costa, for providing the facilities for the experiment, and Mr. Auro Pires, for assistance in carrying out the experiments.

\section{RESUMO}

Níveis de biossólido equivalentes a 0, 28, 56 e 112 $\mathrm{t} \mathrm{ha}^{-1}$ foram avaliados no desenvolvimento de Mentha piperita L. Determinaram-se área foliar e matéria seca total e dos diferentes órgãos, os índices fisiológicos razão de área foliar, área foliar específica, taxa assimilatória líquida e taxa de crescimento relativo, aos 30, 44, 58, 72 e 86 dias após plantio (DAP) e o rendimento de óleo essencial aos 90, 110 e 120 DAP. Os índices fisiológicos revelaram que o biossólido prolongou a fase vegetativa das plantas, que se adaptaram com o tempo e apresentaram comportamentos inversos em relação à produtividade, resultado de seu metabolismo primário e representada pela produção de matéria seca da parte aérea e produção de óleo, resultado do metabolismo secundário. A referida adaptação das plantas de menta à presença do biossólido pode ser devido à função fitorremediadora dessa espécie, cujos mecanismos intrínsecos poderão ser melhor compreendidos na avaliação dos efeitos residuais em sua parte aérea.

\section{REFERENCES}

Bacarin, M. A.; Mosquin, P. R. (1997), Estudo do comportamento de dois genótipos de Phaseolus vulgaris L. de produtividade contrastante. I. Análise de crescimento. Ciênc. Agrotec., 21(2), 233-236. 
Benincasa, M. M. P. (2003), Análise de Crescimento de Plantas: Noções Básicas. FUNEP, Jaboticabal.

Berton, R. S., Camargo, O. A., Valadares, J. M. A. S. (1989), Absorção de nutrientes pelo milho em resposta à adição de lodo de esgoto a cinco solos paulistas. Rev. Bras. Ciênc. Solo 13, 187-192.

Bettiol, W. and Camargo, O. A. (2000), Impacto Ambiental do Uso Agrícola do Lodo de Esgoto. Embrapa, Jaguariúna.

Boaro, C. S. F., Rodrigues, J. D., Pedras, J. F., Rodrigues, S. D., Delachiave, M. E. A., Ono, E. O. (1996), Avaliação do crescimento do feijoeiro (Phaseolus vulgaris L. cv. Carioca) sob diferentes níveis de magnésio. Biotemas, 9(2), 15-28.

Borges, M. R. and Coutinho, E. L. M. (2004), Metais pesados do solo após aplicação de biossólido. II disponibilidade. Rev. Bras. Ciênc. Solo, 28, 557-568.

Brallier, S., Harrison, R., Henry, C., Dongsen, X. (1996), Liming effects on availability of $\mathrm{Cd}, \mathrm{Cu}, \mathrm{Ni}$ and $\mathrm{Zn}$ in soil amended with sewage sludge 16 years previously. Water Air Soil Poll., 86, 195-206.

Brandes, D., Maestri, M., Vieira, C., Gomes, F. R. (1973), Efeitos da população de plantas e da época de plantio no crescimento do feijoeiro (Phaseolus vulgaris L.). II-Análise de crescimento. Experientiae, 15(1), 1-21.

Bugbee, J. G. (2002), Growth of ornamental plants in container media amended with biosolids compost. Comp. Sci. Util., 10(2), 92-98.

Clark, R. J. and Menary, R. C. (1980), Environmental effects on peppermints (Mentha piperita L.) I. Effects of day length, photon flux density, night temperature and day temperature on the yield and composition of peppermint oil. Aust. J. Plant Physiol., 7, 685-692.

Consolini, F. and Coutinho, E. L. M. (2004), Efeito da aplicação de $\mathrm{Zn}$ e do $\mathrm{pH}$ do solo na disponibilidade do micronutriente. Acta Sci., 26(1), 7-12.

Croteau, R. and Johnson, M. A. (1984), Biosynthesis of terpenoids in glandular trichomes. In-Biology and Chemistry of Plant Trichomes, eds. E., Rodriguez; P. L. Healey; I. Mehta. Plenum Publishing, New York, pp. 133-185.

Czepak, M. P. (1998), Produção de óleo bruto e mentol cristalizável em oito frequiências de colheita da menta (Menta arvensis L.). In Plantas Medicinais, Aromáticas e Condimentares, Avanços na Pesquisa Agronômica (L.C. Ming, ed.). Faculty of Agronomic Sciences, Botucatu, pp. 53-80.

Fernandes, P. C.; Facanali, R.; Teixeira, J. P. F.; Furlani, P. R.; Marques, M. O. M. (2004), Cultivo de manjericão em hidroponia e em diferentes substratos sob ambiente protegido. Hortic. Bras., 22(2), 260264.

Ferreira, E. (1996), Ajustamento osmótico e análise de crescimento de plantas de milho (Zea mays L.), em função do nível de potássio e estresse hídrico. Ms. Thesis, Paulista State University, Botucatu, Brazil.
GEPEQ - Grupo de Pesquisa em Educação Química. Projeto Hidroponia. Instituto de Química, Universidade de São Paulo. Disponível em: http://gepeq.iq.usp.br/hidroponia.htm. Acesso em: 17 out 2006.

Korboulewsky, N., Bonin, G., Massini, C. (2002), Biological and ecophysiological reactions of white wall rocket (Diplotaxis erucoides L.) grown on sewage sludge compost. Environ. Poll. 117(2), 365370 .

Leal, F. P. (2001), Desenvolvimento, produção e composição de óleo essencial da Mentha piperita L., cultivada em solução nutritiva com diferentes níveis de nitrogênio. Ms. Thesis, Paulista State University, Botucatu, Brazil.

Lorenzi, H. and Matos, F. J. A. (2002), Plantas Medicinais do Brazil: Nativas e Exóticas. Instituto Plantarum, Nova Odessa.

Lund, Z. F., Doss, B. D. (1980), Residual effects of dairy cattle manure on plant growth and soil properties. Agron. J., 72, 123-130.

Magalhães, A. C. N. (1986), Análise quantitativa de crescimento. In-Fisiologia Vegetal, ed. M. G. Ferri. EDUSP, São Paulo, p.331.

Maisonnave, V., Montrejaud-Vignoles, M., Bonnin, C., Revel, J.C. (2002), Impact on crops, plants and soils of metal trace elements transfer and flux, after spreading of fertilizers and biosolids. Water Sci. Technol., 46(10), 217-224.

Marotti, M., Dellacecca, V., Piccaglia, R., Giovanelli, E. (1997), Effect of harvesting stage on the yield and essential oil composition of peppermint (Mentha $\mathrm{x}$ piperita L.). Acta Hortic., 344, 370-377.

Mata-González, R., Sosebee, R. E., Changgui, W. (2002), Physiological impacts of biosolids application in desert grasses. Environ. Exper. Bot., 48(2), 139148.

Melo, W. J. and Marques, M. O. (2000), Potencial do lodo de esgoto como fonte de nutrientes para as plantas. In-Impacto Ambiental do Uso Agrícola do Lodo de Esgoto, eds. W. Bettiol and O.A. Camargo. Embrapa, Jaguariúna, pp.109-143.

Milthorpe, F. L. and Moorby, J. (1974), Some aspects of overall growth and its modification. In- $A n$ Introduction to Crop Physiology, eds. F.L. Milthorpe and J. Moorby. Cambridge University Press, London, p.152.

Munsi, P. S. (1992), Nitrogen and phosphorus nutrition response in japanese mint cultivation. Acta Hortic., 306, 436-442.

Patra, D. D. and Anwar, M. (2000), Integrated nutrient management and waste recycling for restoring soil fertility and productivity in Japanese mint and mustard sequence in Uttar Pradesh, India. Agric. Ecosys. Environ., 80(3), 267-275.

Piccaglia, R., Dellacecca, V., Marotti, M., Giovanelli, E. (1993), Agronomic factors affecting the yields and 
the essential oil composition of peppermint (Mentha $x$ piperita L.). Acta Hortic., 344, 29-40.

Pigozzo, A. T. J., Lenzi, E., Luca Junior, J., Scapim, C.A., Costa, A. C. S. (2006), Transition metal rates in latosol twice treated with sewage sludge. Braz. Arch. Biol. Technol. 49(3), 515-526.

Portes, T. A., Castro Junior, L. G. (1991), Análise de crescimento de plantas: um programa computacional auxiliar. Braz. J. Plant Physiol., 3, 53-56.

Reitsma, R. H., Cramer, F. J., Scully, N. J., Chorney, W. (1961), Essential oil synthesis in mint. J. Pharm. Sci. 50:18-21.

Salisbury, F. and Ross, C. W. (1992), Plant Physiology. Wadsworth, California.

SAS - The Statistical Analysis System (1996), SAS Institute Inc., USA.

Scavroni, J., Boaro, C. S. F., Marques, M. O. M., Ferreira, L. C. (2005), Yield and composition of the essential oil of Mentha piperita L. (Lamiaceae) grown with biosolid. Braz. J. Plant Physiol., 17(4), 345-352.

Scora, R. W., Chang, A. C. (1997), Essential oil quality and heavy metal concentrations of peppermint grown on a municipal sludge-amended soil. J. Environ. Qual., 26(4), 975-979.

Srivastava, N. K. and Luthra, R. (1994), Relationship between photosynthetic carbon metabolism and essential oil biogenesis in peppermint under $\mathrm{Mn}$ stress. J. Exp. Bot., 45, 1127-1132.

Taiz, L., Zeiger, E. (2004), Fisiologia Vegetal. ARTMED, Porto Alegre.

Topalov, V. and Zhelyazkov, V. (1991), Effect of harvesting on the yield of fresh material, essential oil, and planting material from Mentha piperita L. and Mentha arvensis L. Herba. Hung., 50, 60-67.
Tsutya, M. T. (2000), Alternativas de disposição final de biossólidos gerados em estações de tratamento de esgotos. In-Impacto Ambiental do Uso Agrícola do Lodo de Esgoto, eds. W. Bettiol and O.A. Camargo. Embrapa, Jaguariúna, pp.69-107.

Valmorbida, J. and Boaro, C. S. F. (2007a), Growth and development of Mentha piperita L. in nutrient solution with three potassium rates. Braz. Arch. Biol. Technol. 50, 379-384.

Valmorbida, J.; Boaro, C. S. F.; Scavroni, J.; David, E. F. S. (2007b), Crescimento de Mentha piperita L. cultivada em solução nutritiva com diferentes doses de potássio. Braz. J. Med. Plants 9(4), 27-31.

Van Raij, B. V., Cantarella, H., Quaggio, J. A., Furlani, A. M. C. (1996), Boletim Técnico 100: Recomendação de Adubação e Calagem para o Estado de São Paulo. Instituto Agronômico and Fundação IAC, Campinas.

Veronese, P., Li, X., Niu, X., Weller, S.C., Bressan, R. A., Hasegawa, P. M. (2001), Bioengineering mint crop improvement. Plant Cell Tissue Organ Cult., 64, 133-144.

Wallace, D. H. and Munger, H. M. (1965), Studies of the physiological basis for yield differences: IGrowth analysis of six dry bean varieties. Crop Sci., 5, 343-348.

Watson, D. J. (1952), The physiological basis of variation in yield. Adv. Agron., 4, 101-144.

Zheljazkov, V. D. and Nielsen, N. E. (1996), Effect of heavy metals on peppermint and cornmint. Plant Soil, 178(1), 59-66. 